\title{
Evaluation of biofilm formation by exopolysaccharide- producer strains of thermophilic lactic acid bacteria isolated from Algerian camel milk
}

\author{
Mostefaoui Abdellah" ${ }^{1 *}$, Hakem Ahcène, Yabrir Benalia', Boutaiba Saad', Badis Abdelmalek ${ }^{2}$ \\ ${ }^{1}$ Laboratory of Exploration and Valorization of Steppic Ecosystems, University of Djelfa, Algeria, ${ }^{2}$ Laboratory of Biochemistry and Industrial \\ Microbiology, Department of Industrial Chemistry, University of Blida I, Algeria
}

\section{A B S T R A C T}

\begin{abstract}
Exploration of wild lactic acid bacteria from natural environments is the most suitable approach of search for the desired exopolysaccharidephenotype. The significance of biofilm in food processing is a highly debated issue. The Biofilm represents the next major scientific challenge to microbiologists and food processors. A total of 30 thermophilic lactic acid bacteria strains were isolated from Algerian raw Camel milk. The isolation was carried on Chalmers agar, under aerobic and anaerobic conditions at $42^{\circ} \mathrm{C}$. The identification, based on the phenotypic characteristics showed high diversity of species and predominance of Lactobacillus and Enterococcus. Based on the mucoid type of the colonies, strains were screened for their ability to produce exopolysaccharides. The production of polymers was carried on modified MRS broth, then, the yields were quantified, using the colorimetric method. The results show that the tested strains produced large amounts of soluble exopolysaccharides, some strains have a potential to be used as culture starters for dairy products. These strains were examined for their ability to form biofilm, using the Biofilm Ring Test. The findings showed that all studied strains formed a biofilm. While, the Biofilm Ring Test with exopolysaccharide powder of different strains, showed positive result for only three Lactobacillus strains (La91, Lb116, La117) that Which suggest that there is no relationship between exopolysaccharide yield and biofilm formation.
\end{abstract}

Keywords: Thermophilic lactic acid bacteria; Exopolysaccharides; Biofilm

\section{INTRODUCTION}

There is an increasing demand in food industries for live microbes producing polysaccharides (Patel et al., 2010). Many lactic acid bacteria (LAB) are able to produce EPS. The dairy LAB used in the manufacture of fermented milks such as Streptococcus thermophilus, Lactobacillus delbrueckii subsp. bulgaricus and Lactococcus lactis subsp. cremoris were extensively studied in the last years (Cerning, 1995). EPS synthesized by LAB play a major role in the manufacturing of fermented dairy products (Duboc and Mollet, 2001; Jolly et al., 2002). These molecules are economically important because they can impart functional effects to foods and confer beneficial health effects (Welman and Maddox, 2003). When suspended or dissolved in aqueous solution, EPS provide thickening and gelling properties (Marshall and Rawson, 1999; Laws and Marshall, 2001). Some EPS confer on $\mathrm{LAB}$ a ropy character that can be detected in cultures that form long strands when extended with an inoculation loop. The screening of ropy strains and the isolation and quantification of EPS have led to the application of a large variety of techniques (Goh et al., 2005; Ruas-Madiedo and de los Reyes-Gavilán, 2005). The amounts of EPS produced by the dairy strains vary considerably (Ludbrook et al., 1997; Laws et al., 2001; Badel et al., 2011).

The attachment of biofilm (BF) bacteria in food processing environments is a potential source of contamination that may lead to food spoilage or transmission of diseases (Wong, 1998). The biofilms are composed of bacteria, microbial EPS and other substances (Tsuneda et al., 2003). In BF, exopolysaccharides play a major role in determining the physical properties and structure of microbial agglomeration, and represent the house of the BF cells (Sutherland, 2001; Mayer et al., 1999; Fleming et al., 2007). In most of the cases where BF are a nuisance, the microbial fouling is generally implied. In dairy and food industry, biofouling causes serious problems (Criado et al.,

\footnotetext{
${ }^{*}$ Corresponding author:

Mostefaoui Abdellah, Laboratory of Exploration and Valorization of Steppic Ecosystems, University of Djelfa, BP 3117 , Po Box 17000 , Algeria. E-mail: m_abdellah2003@yahoo.fr, Phone: 00 21327877763, Fax: 0021327909376
} 
1994). In nature and food systems, microorganisms get attracted to solid surfaces conditioned with nutrients that are sufficient for their viability and growth. In this regard, the formation of organic polymers is essential because it helps in the proper colonization of microorganisms (Allison and Sutherland, 1987). Many bacterial species are able to live in BF, an evidence implicating $\mathrm{BF}$ as the cause of various human infections (Kaur et al., 2009). Nonstarter LAB are common causes of cheese defects, such as undesirable flavors, gas formation, and the white haze from calcium lactate crystals. The source of these bacteria is primarily from post pasteurization contamination in the dairy plant environment (Peterson et al., 1990). Biofilms have been of considerable interest in the context of food hygiene. BF formation is a dynamic process and different mechanisms are involved in their attachment and growth. Various techniques have been adopted for the proper study and understanding of $\mathrm{BF}$ attachment and control (Kumar and Anand, 1998).

Based on the previous data, our problematic was the search for new EPS-producing strains with desirable properties and at the same time, to provide responses to the question of the relationships between bacterial EPS and $\mathrm{BF}$ formation. Up to now, camel milk was not deeply investigated for the characterization of thermophilic bacteria (Akhmetsadykova et al., 2014).

In the current study, thirty (30) strains of TLAB isolated from Algerian raw Camel milk were taxonomically characterized using the phenotypic methods. On the other hand, these strains were first screened for their capacity to produce exopolysaccharides, using the conventional assay, and there were secondary examined for their ability to form a BF, using the Biofilm Ring Test. While, the EPS powders were also tested for biofilm formation.

\section{MATERIAL AND METHODS}

\section{Sampling and isolation of TLAB strains}

Samples of raw camel milk were obtained from the south of Algeria. Samples were collected in sterile bottles until transported to the laboratory, and the $\mathrm{pH}$ of each sample was measured and the microbiological analyses were performed at the arrival. The strains isolation was carried out after milk acidification to retrieve a large diversity of TLAB (Khedid et al., 2009). Ten $\mathrm{ml}$ of each sample were mixed with $90 \mathrm{ml}$ of sterile yeast water $(10 \% \mathrm{w} / \mathrm{v}$, Oxoid), and serial decimal dilutions were carried out. Isolation of TLAB was performed by the standard pour-plate method, using modified Chalmers-agar medium (Vanos and Cox, 1986). Plates were incubated an-aerobically and semi an-aerobically for $72 \mathrm{~h}$ at $42^{\circ} \mathrm{C}$. The LAB colonies were picked and purified on MRS-agar plates (De Man et al., 1960), and strains were kept frozen at $-20^{\circ} \mathrm{C}$ in MRS broth supplemented with $10 \%$ glycerol.

\section{Phenotypic identification of TLAB isolates}

TLAB strains were identified according to many recommended methods (Sharpe, 1979; Samelis et al., 1994; Harrigan, 1998; Badis et al., 2004; Khedid et al., 2009). All isolates were initially Gram stained and examined for cell morphology and motility, then were examined using different kinds of tests; growth at different temperatures $\left(10,15,30,37\right.$ and $\left.45^{\circ} \mathrm{C}\right)$ and at different $\mathrm{pH}(4.2$ and 9.6), as well as salt tolerance $(2 \%, 6.5 \%$ and $18 \%$ of $\mathrm{NaCl})$ in MRS broth (Oxoid), catalase and oxidase reactions, gas production from glucose, ammonia from arginine hydrolysis, ketone production (Voges-Proskauer test), utilization of citrate and heat resistance at $60.5^{\circ} \mathrm{C}$ for 30 minutes. The fermentation of carbohydrates (arabinose, cellobiose, aesculin, fructose, galactose, glucose, lactose, maltose, mannitol, mannose, melezitose, melibiose, raffinose, rhamnose, ribose, sucrose, sorbitol, trehalose and xylose) was performed in MRS broth containing 1\% solution of carbohydrate and bromocresol purple as $\mathrm{pH}$ indicator. Results were recorded after $48 \mathrm{~h}$ of incubation at $42^{\circ} \mathrm{C}$. Tests were repeated two times to avoid confusing results in the identification. The isolates were preliminary subdivided into 4 groups:

- Homofermentative and Gram positive, catalase negative, cocci which grew at $10^{\circ} \mathrm{C}$ and $45^{\circ} \mathrm{C}$, grew in the presence of $6.5 \%$ of $\mathrm{NaCl}$ and at $\mathrm{pH} 9.6$ were considered as presumptive Enterococcus.

- Homofermentative and Gram positive, catalase negative, cocci in pairs or in tetrads which grew at $45^{\circ} \mathrm{C}$ but not at $10^{\circ} \mathrm{C}$, were considered as presumptive Pediococcus.

- Homofermentative and Gram positive, catalase negative, cocci in chain cells, which grew at $45^{\circ} \mathrm{C}$ but not at $10^{\circ} \mathrm{C}$, were considered as presumptive Streptococcus.

- Homofermentative and Gram positive, catalase negative, rods, which grew at $45^{\circ} \mathrm{C}$ but not at $15^{\circ} \mathrm{C}$, pentose non-fermented, absence of gas production from glucose, were considered as presumptive Lactobacillus.

\section{Screening test for mucoidy and ropiness}

Screening test was carried on customized MRS-agar medium (Degeest and De Vuyst, 1999; Degeest et al., 2001; 2002). TLAB Strains were plated and incubated under anaerobic and semi anaerobic conditions at $42^{\circ} \mathrm{C}$ for $72 \mathrm{~h}$. At the end of incubation, mucoidy of colonies was determined by visual appearance, and ropiness was determined by touching them with a sterile inoculation loop (Ricciardi et al., 1997; Welman et al., 2003; Ruas-Madiedo 
and de los Reyes-Gavilán, 2005). Colonies which have mucoid and ropy phenotype were picked up and purified by following the streaking method, then preserved at $4^{\circ} \mathrm{C}$ on MRS agar slants (Vijayendra et al., 2008) and selected for the next step.

\section{Exopolysaccharides production}

Customized MRS broth was used for fermentations. It contained (in grams/liter): lactose (75), glucose (25), peptone (30), yeast extract (12), Lab Lemco (8), $\mathrm{K}_{2} \mathrm{HPO}_{4}$ (2), sodium acetate (5), tri-ammonium citrate (2), $\mathrm{MgSO}_{4}{ }^{-}$ $7 \mathrm{H}_{2} \mathrm{O}(0.2), \mathrm{MnSO}_{4}-\mathrm{H}_{2} \mathrm{O}$ (0.038), and Twin 80 (1 ml/liter). The unfermented medium was ultra-filtered under 10000 Da., using a tangential filtration system, in order to eliminate polysaccharides from yeast extract which would have interfered with the purification and determination of EPS composition (Ricciardi et al., 2002; Shene et al., 2008). Sterilization was performed by microfiltration under $0.22 \mu \mathrm{m}$ using a steritop (Millipore).

The strains were stored at $-20^{\circ} \mathrm{C}$ in MRS broth (Oxoid), containing $25 \%(\mathrm{v} / \mathrm{v})$ glycerol. The inoculums were also prepared in $10 \mathrm{ml}$ of customized MRS inoculated with $100 \mu \mathrm{l}$ of freshly prepared cultures. After incubation at $40^{\circ} \mathrm{C}$ for $24 \mathrm{~h}$, they were adjusted to $\mathrm{OD}_{600}=1$ and transferred into $500 \mathrm{ml}$ Erlenmeyer flasks containing $90 \mathrm{ml}$ of fermented medium. Fermentations were performed at $40^{\circ} \mathrm{C}$ for $24 \mathrm{~h}$. Agitation was maintained at $100 \mathrm{rpm}$ to provide adequate dispersion (Gancel and Novel, 1994; Vaningelgem et al., 2004).

\section{Isolation and quantification of exopolysaccharides}

Exopolysaccharides were purified from the various culture strains using method of Ruas-Madiedo and los ReyesGavilán (2005), with some modifications. Grown cultures were heated in boiling water for 15 min to inactivate enzymes, and then cooled down to room temperature, centrifuged (20 min, $10000 \mathrm{~g}$ ) to remove cells and coagulated proteins, then the supernatant was collected. EPS were precipitated from the supernatant with three volumes of cold ethanol (96\%) followed by an overnight incubation at $-20^{\circ} \mathrm{C}$. After centrifugation $(20 \mathrm{~min}, 10000 \mathrm{~g}$, $4^{\circ} \mathrm{C}$ ), the precipitates were re-suspended in hot ultrapure (Milli-Q) water and dialyzed (molecular weight cut-off: 10000 Da.) for 2 days against ultrapure water (changed twice each day). EPS solution was then frozen at $-80^{\circ} \mathrm{C}$ and lyophilized. The EPS powder was determined by measuring the dry weight of the precipitate, and stored for further analysis. Total sugar content was measured according to the phenol-sulfuric acid method of Dubois et al. (1956), using glucose as standard. Thus, Proteins content was determined according to the Bradford method (1976), using BSA as standard.

\section{Evaluation of bacterial biofilm formation}

Using the Biofilm Ring Test developed by the Biofilm Control Society as described by Chavant et al., (2007), EPSproducing strains of TLAB were tested for their ability to form BF (Leroy et al., 2009). Overnight cultures in BHI (Brain Heart Infusion supplemented with 1\% lactose, Difco) broth were diluted in fresh BHI in order to obtain an $\mathrm{OD}_{600}=1$. Then, $40 \mu \mathrm{l}$ were inoculated in $10 \mathrm{ml}$ of sterile $\mathrm{BHI}$ corresponding to the initial bacterial suspension for each bacterial strain. The Toner was added in each suspension to get a final concentration of $12 \mu \mathrm{m} \mathrm{ml}^{-1}$. This mixture was homogenized by vortex and $200 \mu \mathrm{l}$ per well were deposited in wells of a 96-well polystyrene micro-plate and incubated at $37^{\circ} \mathrm{C}$ for $0,6,12$, or $24 \mathrm{~h}$. Controls were sterile $\mathrm{BHI}$ and magnetic beads. Wells of each strip were first covered with $100 \mu \mathrm{l}$ of Contrast Liquid and scanned with the Plate Reader (scanner), to get an $\mathrm{I}_{0}$ image. Then, the strip was placed for 1 minute on the Block Test and scanned again to get an $\mathrm{I}_{1}$ image. If no $\mathrm{BF}$ was formed, the magnetic beads subjected to a magnetic field (magnets applied on the bottom center of each well) were clumped and formed a spot at the bottom of the well. If a BF was formed, the magnetic beads were completely or partly immobilized, and spot formation was absent or reduced in response to the magnetic field. Three independent tests were performed per strain and incubation time to determine the biofilm indices (BFI). Images of each well before and after magnetization $\left(\mathrm{I}_{0}\right.$ and $\mathrm{I}_{1}$ ) were compared with the BF Control Software. An algorithm estimated the discrepancy between the two images of a same well, giving a value named the BFI ranging from 0 to 20 . A high $\mathrm{BFI}$ value corresponded to a high mobility of beads under magnet action and indicated that the bacterial population did not form $\mathrm{BF}$, while a low value $(\leq 2)$ correspond to immobilization of beads by cells forming a biofilm.

\section{Effect of EPS powder on the biofilm ring test}

The lyophilized exopolysaccharides were dissolved at different concentrations, ranged from 0.25 to $1 \mathrm{~g} / \mathrm{L}$ in a sterile BHI medium. Strips were filled per different concentrations of EPS powder, in a micro-plate of the Biofilm Ring Test, and the BFI values were determined. A control of BHI medium without EPS was tested (Badel et al., 2008).

\section{RESULTS}

\section{Phenotypic identification of TLAB strains}

After the preliminary characterization, a set of thirty Gram positive, catalase and oxidase negative, no spore forming and homo-fermentative isolates, obtained from modified Chalmers medium (incubated at $42^{\circ} \mathrm{C}$ for 2 or 3 days), were investigated for their phenotypic characters on the 
MRS medium (Table 1). The isolates were preliminary belonged to the following genera and species. Twelve (12) rod shaped strains were considered as Lactobacilli and according to their fermentative profile, they were identified to the presumptive species: Lactobacillus delbrueckii subsp. bulgaricus (20\%), Lactobacillus helveticus (10\%) and Lactobacillus acidophilus (10\%). Nine (9) cocci shaped strains, in pairs or in chain cells, which were classified into Streptococcus salivarus subsp. thermophilus (30\%). Seven (7) cocci shaped strains, were considered as Enterococcus faecium (23.33\%). Two (2) cocci shaped strains, in pairs or in tetrads, were identified as Pediococcus acidilactici (6.66\%).

\section{Screening for EPS-producing phenotype}

The screening test for EPS-producing phenotype revealed the presence of mucoidy and ropiness in colonies of all strains in our culture collection.

\section{EPS production, isolation and determination}

The investigation in the second step of screening for EPS production by TLAB isolated from raw Camel milk, showed that a majority of selected strains produced EPS with more than $0.1 \mathrm{~g} / \mathrm{l}$; The EPS yield of Lactobacilli strains ranged between $0.16 \mathrm{~g} / 1$ and $0.74 \mathrm{~g} / 1$, Streptococci EPS amount ranged between $0.126 \mathrm{~g} / \mathrm{l}$ and $0.319 \mathrm{~g} / \mathrm{l}$, Enterococci EPS yield ranged between $0.07 \mathrm{~g} / \mathrm{l}$ and $0.242 \mathrm{~g} / \mathrm{l}$ and Pediococci EPS yield was greater than $0.13 \mathrm{~g} / \mathrm{l}$. Lactobacilli strain (Lb115) had the highest EPS yield, while the Enterococci strain (Ef28) had the lowest EPS yield. The total sugar content in EPS powders was in the range of 9.49 to $77.37 \%$ for Enterococci and 50.57 to $58.69 \%$ for Pediococci strains, whereas, proteins accounted for low than $4.86 \%$ for all studied strains (Fig. 1).

\section{Evaluation of biofilm formation by TLAB cultures}

The screening test used here for evaluating biofilm formation of pure bacterial cultures in BHI medium, showed that all the EPS-producing strains of TLAB isolated from Algerian Camel milk, have the ability to form $\mathrm{BF}$ on the a-biotic surface. Ninety-three $\%$ of the tested strains produced $\mathrm{BF}$ after $6 \mathrm{~h}$ of incubation, and $7 \%$ after $12 \mathrm{~h}$. This diversity in kinetic of BF formation was observed with Streptococcus thermophilus strains, while, the other strains of Lactobacillus, Enterococcus and Pediococcus species reveals comparatively the same kinetic (Fig. 2).

\section{Evaluation of biofilm formation by EPS powders}

The Biofilm Ring Test with solutions of EPS powders showed that just three samples reacted positively (Fig. 3), these EPS being produced by two strains of Lactobacillus acidophilus (La91, La117) and one strain of Lactobacillus bulgaricus (Lb116) have a viscous appearance. BFI values varied inversely and proportionally to the concentration of EPS (Fig. 4).
Table 1: Phenotypic criteria of presumptive species of TLAB

\begin{tabular}{|c|c|c|c|c|c|c|}
\hline \multirow[t]{2}{*}{ Characters } & \multicolumn{6}{|c|}{ Presumptive species of TLAB } \\
\hline & $\operatorname{La}(3)^{*}$ & $L b(6)^{*}$ & $\operatorname{Lh}(3)^{*}$ & $E f(7)^{*}$ & $\mathrm{~Pa} \mathrm{(2)*}$ & St $(9)^{*}$ \\
\hline Motility & - & - & - & - & - & - \\
\hline Gram stains & + & + & + & + & + & + \\
\hline Presence of spore & - & - & - & - & - & - \\
\hline Cell shape & $\mathrm{R}$ & $\mathrm{R}$ & $\mathrm{R}$ & $\mathrm{C}$ & $\mathrm{Ct}$ & $\mathrm{C}$ \\
\hline Catalase & - & - & - & - & - & - \\
\hline Oxidase & - & - & - & - & - & - \\
\hline Growth at: pH 4.2 & + & + & + & v & + & + \\
\hline $\mathrm{pH} 9.6$ & - & - & - & + & - & - \\
\hline Growth in: $2 \% \mathrm{NaCl}$ & + & + & + & + & + & + \\
\hline $6.5 \% \mathrm{NaCl}$ & - & - & - & + & v & - \\
\hline $18 \% \mathrm{NaCl}$ & - & - & - & - & - & - \\
\hline Growth at: $10^{\circ} \mathrm{C}$ & - & - & - & + & - & - \\
\hline $15^{\circ} \mathrm{C}$ & - & - & - & + & - & - \\
\hline $30^{\circ} \mathrm{C}$ & - & - & - & + & - & - \\
\hline $37^{\circ} \mathrm{C}$ & + & + & + & + & + & + \\
\hline $45^{\circ} \mathrm{C}$ & + & + & + & + & + & + \\
\hline $\begin{array}{l}\text { Survive at } 63^{\circ} \mathrm{C} \text { for } \\
30 \mathrm{~min}\end{array}$ & + & $v$ & + & v & + & + \\
\hline $\mathrm{CO}_{2}$ from glucose & - & - & - & - & - & - \\
\hline $\mathrm{NH}_{3}$ from arginine & - & - & - & + & + & - \\
\hline Production of ketone & - & - & - & v & + & - \\
\hline Hydrolysis of citrate & - & - & - & v & - & - \\
\hline Hydrolysis of aesculin & - & - & - & + & + & - \\
\hline $\begin{array}{l}\text { Fermentation of } \\
\text { arabinose }\end{array}$ & - & - & - & + & v & - \\
\hline Ribose & - & - & - & + & - & - \\
\hline Xylose & - & - & - & - & v & - \\
\hline Fructose & + & + & - & + & + & $v$ \\
\hline Galactose & + & + & + & + & + & - \\
\hline Glucose & + & + & + & + & + & + \\
\hline Mannose & - & + & v & + & + & - \\
\hline Rhamnose & - & - & - & v & - & $v$ \\
\hline Glycerol & - & - & - & v & v & - \\
\hline Mannitol & - & - & - & + & - & - \\
\hline Sorbitol & - & - & - & + & - & - \\
\hline Cellobiose & V & $v$ & - & + & + & v \\
\hline Lactose & + & + & + & + & v & + \\
\hline Maltose & - & + & + & + & + & v \\
\hline Melibiose & - & - & - & $\mathrm{v}$ & - & - \\
\hline Sucrose & - & + & - & + & v & + \\
\hline Trehalose & - & + & v & + & + & - \\
\hline Melezitose & - & - & - & + & - & - \\
\hline Raffinose & - & - & - & v & - & - \\
\hline
\end{tabular}

Note: La: Lactobacillus acidophilus, Lb: Lactobacillus delbrueckii subsp. bulgaricus, Lh: Lactobacillus helviticus. Ef: Enterococcus faecium, Pa: Pediococcus acidilactici, St: Streptococcus salivarus subsp. thermophilus, R: Rod, C: Cocci, Ct: Cocci/tetrads, +: More than $90 \%$ of strains showed a positive result, -: More than $90 \%$ of strains showed a negative result, $v$ : Between 10 and $90 \%$ of strains showed a positive or negative result. (.)*: Strains number

\section{DISCUSSION}

All bacterial strains isolated from the raw Camel milk samples fit the classification of lactic acid bacteria. TLAB were presents in fermented raw camel milk, because of their ability to produce high levels of lactic acid as well as 


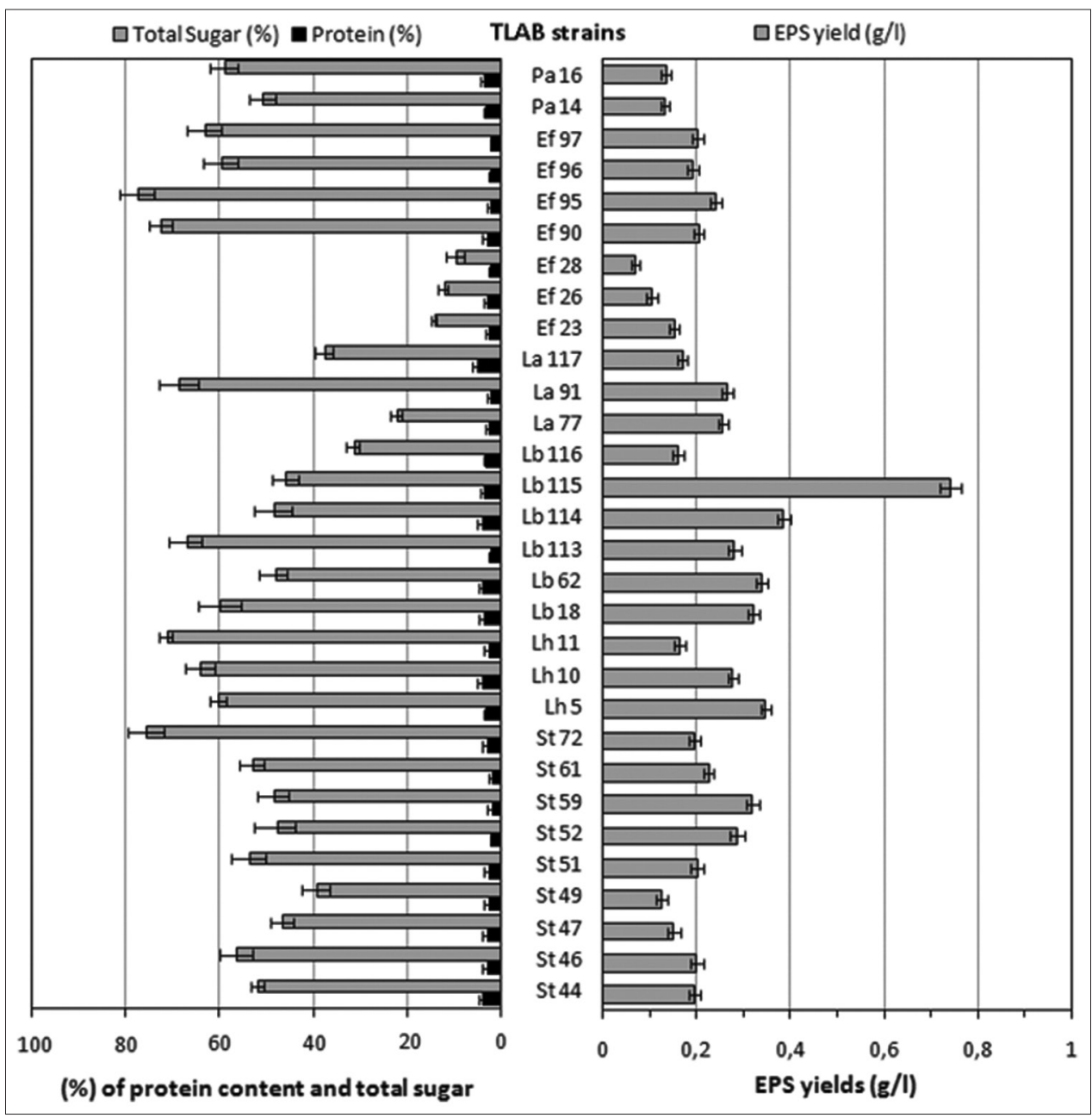

Fig 1. Screening of the TLAB strains for EPS production and partial characterization of produced exopolysaccharides [EPS yields (g/l), Total sugar and proteins content]. La: Lactobacillus acidophilus, Lb: Lactobacillus delbrueckii subsp. bulgaricus, Lh: Lactobacillus helviticus. Ef: Enterococcus faecium, Pa: Pediococcus acidilactici, St: Streptococcus salivarus subsp. thermophilus

being able to survive under high acidic conditions. Thus, it was noted that except some enterococci, all TLAB strains isolated from the fermented raw Camel milk were unable to grow at temperature $30^{\circ} \mathrm{C}$. The high level of TLAB in raw milk can be favored by low $\mathrm{pH}$ conditions (Badis et al., 2004). Results showed high diversity of TLAB found and predominance of lactobacilli and enterococci. These findings are relatively similar to those reported by Benkerroum et al. (2003) and Khedid et al. (2009) in raw dromedary milk of Morocco, Kacem and Karam (2006); Kacem and Kaid-Harche (2008) in camel milk from arid regions of Algeria, Zamfir et al. (2006) in Romanian dairy products and Abdelgadir et al. (2008) in the Sudanese fermented camel milk.

A wide range of bacteria are known to produce EPS. Several LAB produce exopolysaccharides that are secreted into the growth media (Cerning et al., 1986; 1988). Bacteria produce EPS under all conditions, but the quantities and the composition of EPS are strain dependent and affected by the nutritional and environmental conditions (Garcia-Garibay and Marshall, 1991). The purpose of this investigation was to obtain the efficient TLAB strains isolated from raw Camel milk which produce high amount of EPS. The first step of screening for EPSproducing phenotype by various thermophilic lactic acid bacteria strains revealed the highest production ability. The selection process of EPS-producing bacterial strains was fundamentally based on the development of mucoid aspect of strain colonies, according to Ricciardi et al. (1997); Welman et al. (2003) and Ruas-Madiedo and de los Reyes-Gavilan (2005), by studying the production of EPS on solid media, by lactic acid bacteria. In other studies, the detection of the mucoid character was related to EPS production by bacteria isolated from polluted water (Fusconi and Godinho, 2002). The presence of EPS can be recognized by the formation of colonies in mucous solid medium (Gomez, 2006). Therefore, the presence of a translucent or creamy material involving a mucoid colony is an indicator of EPS production potential. The 
production of polymers was confirmed by mixing each colony in absolute ethanol. Precipitate formation indicates the presence of EPS. The discriminatory value of the methods to test mucoidy and ropiness of bacterial colonies, were relatively low. Different EPS screening methods have been reported for LAB. The visual inspection of bacterial colonies on agar plates is most probably the easiest method, but it is insensitive and indicative. This method is unable to detect LAB strains that produce low amounts of EPS (Smitinont et al., 1999; Van den Berg et al., 1993). In the second step, screening of TLAB strains isolated

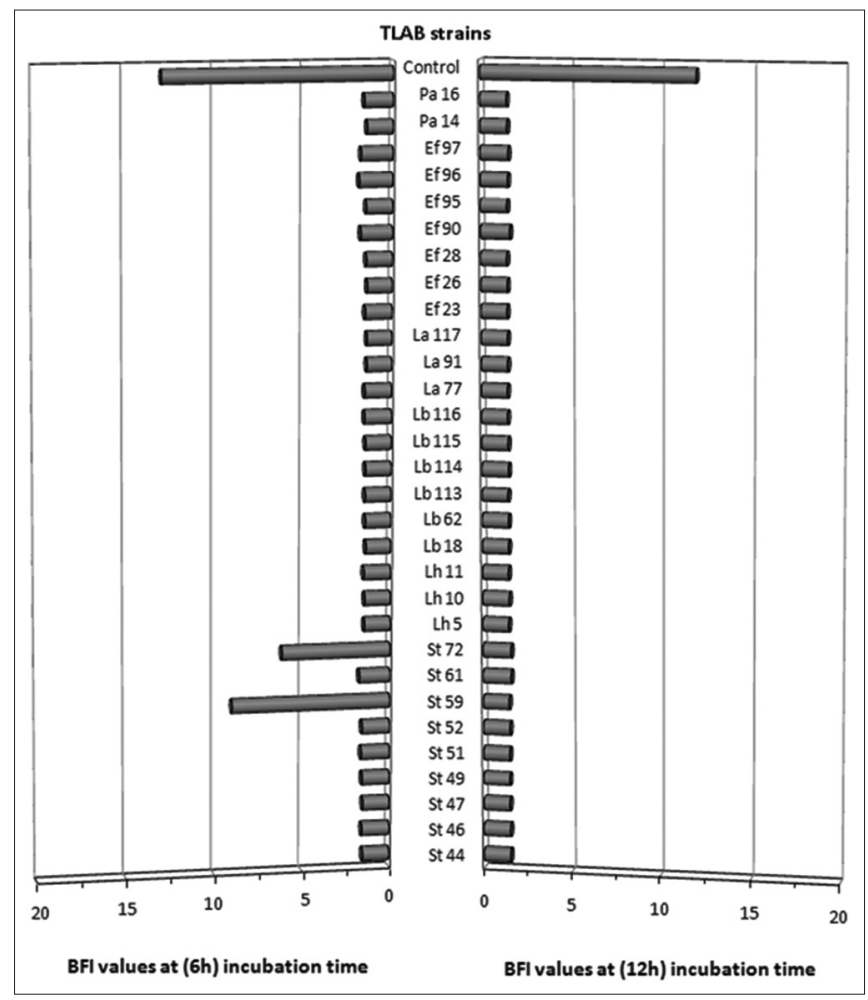

Fig 2. Kinetic of biofilm formation of TLAB cultures (BFI values after 6 and $12 \mathrm{~h}$ incubation time. La: Lactobacillus acidophilus, Lb: Lactobacillus delbrueckii subsp. bulgaricus, Lh: Lactobacillus helviticus. Ef: Enterococcus faecium, St: Streptococcus salivarus subsp. thermophilus, Pa: Pediococcus acidilactici. from raw Camel milk for EPS production was carried out aerobically on customized MRS broth, supplemented with lactose and glucose as carbon source. Many authors studied the effect of medium composition, temperature, $\mathrm{pH}$ and fermentation time on the bacterial growth and exopolysaccharide yields (Cerning, 1990; Degeest and De Vuyst, 1999; Degeest et al., 2001; 2002; Zisu and Shah, 2003; Vaningelgem et al., 2004). Ultra-filtration at $10000 \mathrm{Da}$. of the MRS broth, before fermentation, was used in order to eliminate polysaccharides which would have interfered with EPS composition, and also, to promote the TLAB growth (Gaudreau et al., 1999; Ricciardi et al., 2002; Shene et al., 2008). The data showed that the 30 mucoid strains were able to produce exopolysaccharides. Thus, the amount of EPS production differs between genera and species within a genus. These findings approve the results about EPS from lactic acid bacteria reported by Van den Berg et al. (1993) for who 30 strains out of 607 tested showed the ability to produce exopolysacchrides. Some of them produced high level of EPS yields, such as lactobacilli strains (Lb115, Lb114, Lb113, Lb5, Lb18) and Streptococci strains (St46, St52, St59, St62); which produced respectively more than 0.3 and $0.2 \mathrm{~g} / 1$ of EPS. This was relatively similar to results obtained by Bouzar et al. (1997); Marshall and Rawson (1999), Frengova et al. (2000) and Chen et al. (2006). However there are no reports of EPS production by enterococci and pediococci. Hence, this study revealed that a number of enterococci strains (E90, Ef95, Ef97) produce EPS yield higher than $0.2 \mathrm{~g} / \mathrm{l}$, and also, pediococci strains (Pa14, Pa16) which produce EPS amount upper than $0.1 \mathrm{~g} / 1$. These findings showed that raw Camel milk can be considered as a potential source of thermophilic lactic acid bacteria that producing exopolysaccharides.

The 30 EPS-producing strains were able to grow in BHI medium at $37^{\circ} \mathrm{C}$ under aerobic conditions. The Biofilm Ring Test was used to examine the capacity to form BF; at the start of the experiment, the beads not blocked by

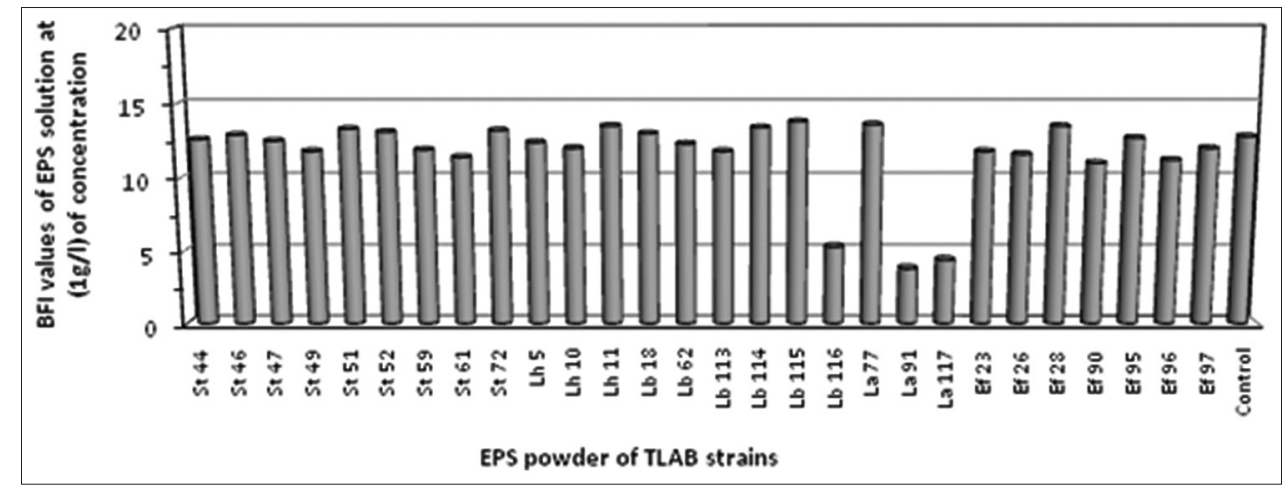

Fig 3. BFI values of EPS Powder solution at (1g/l) concentration from various TLAB strains, La: Lactobacillus acidophilus, Lb: Lactobacillus delbrueckii subsp. bulgaricus, Lh: Lactobacillus helviticus. Ef: Enterococcus faecium, St: Streptococcus salivarus subsp. thermophilus. 


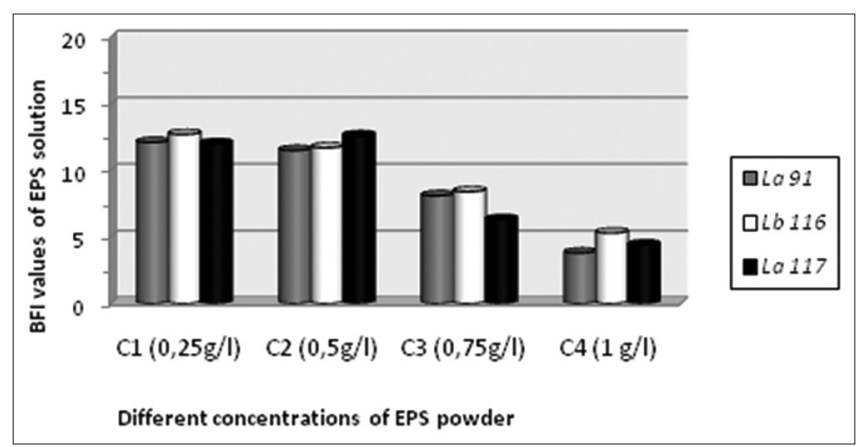

Fig 4. BFI values of EPS solution at different concentrations from three lactobacilli strains, La: Lactobacillus acidophilus, Lb: Lactobacillus delbrueckii subsp. bulgaricus.

the bacteria displayed high mobility. After a period of incubation, the strains producing a BF could immobilize the beads. All the 30 TLAB strains, were found to be biofilm-producers after 6 or $12 \mathrm{~h}$ incubation, the cells quickly forming aggregates with sufficient cohesion to offer resistance to the magnetic attraction forces applied to the magnetic beads. These results are approved by the research of Free et al. (2001) on the biofilm formation by some probiotic bacteria, and could be compared with the results obtained by Leroy et al. (2009) who studied the biofilm formation by Staphylococcus strains isolated from naturally fermented sausages. Diversity in kinetic of BF formation has been observed within the species, for Streptococcus thermophilus. The ability of TLAB strains to form biofilm was not correlated with their EPS yield and their taxonomy, the fact that the strains: Lb115 (Lactobacillus bulgaricus, $0.74 \mathrm{~g} / \mathrm{l}$ ), Ef28 (Enterococcus faecium, $0.07 \mathrm{~g} / \mathrm{l}$ ), St52 (Streptococcus thermophilus, $0.286 \mathrm{~g} / \mathrm{l}$ ) and Pa16 (Pediococcus acidilactici, $0.134 \mathrm{~g} / \mathrm{l}$ ) showed relatively the same kinetics of BF formation, despite their taxonomic diversity and their variable EPS yield. The results of Biofilm Ring Test with EPS solutions eliminates the hypothesis of the effect of EPS yield on the BF formation, and suggests that the viscosity of EPS can influence the biofilm forming activity in bacterial cultures.

\section{CONCLUSION}

Our results demonstrate the diversity of TLAB in Algerian raw Camel milk. This dairy product contains several genera of LAB, which were preliminary identified, and had a potential for EPS-producing activity with high yields. These strains can be used as starter culture with predictable characteristics and contribute to the development of fermented foods with stable consistent quality. These strains are all able to form biofilm in abiotic environment. While, their EPS powder reacted negatively with the Biofilm Ring Test, except for three strains (La91, Lb116 and La117), which had moderate yield of EPS with a viscous appearance. In the future, some of these strains will be identified and optimized for their EPS-producing activity, then, exopolysaccharides can be characterized, and applied according to the physicochemical characteristics.

\section{Abbreviations}

EPS: exopolysaccharides, LAB: lactic acid bacteria, TLAB: thermophilic lactic acid bacteria, OD: optical density, BSA: Bovine Serum Albumin, BF: biofilm, IBF: index of biofilm, BHI: brain heart infusion.

\section{ACKNOWLEDGEMENTS}

The authors are grateful to Dr Thierry Bernardi (Society of Biofilm Control), Prof. Philippe Michaud (L.G.C.B. laboratory) and all the laboratory staff to provide the necessary equipment and constant assistance during the research period, and also, authors wish to thank Mr. Mustapha Touati ( $\mathrm{PhD}$ student) for revision of the English.

\section{Authors contributions}

A. M. made a major contribution to this article, was involved in conception and design of study, exopolysaccharides characterization and biofilm analysis of lactic acid bacteria. A.H. (Director of our laboratory: Exploration and), was involved in supervisor of the research project. B.Y. was involved in sampling, physicochemical analysis of milk samples and acquisition of data and interpretation. S.B. was involved in microbiological analysis of milk samples and bacterial isolation and identification. A. B. (Director of the $\mathrm{PhD}$ project), was involved in conception and design of study.

\section{REFERENCES}

Abdelgadir, W., D. S. Nielsen, S. Hamad and M. Jakobsen. 2008. A traditional Sudanese fermented camel's milk product, Gariss, as a habitat of Streptococcus infantarius subsp. infantarius. Int. J. Food Microbiol. 127: 215-219.

Akhmetsadykova, S., A. Baubekova, G. Konuspayeva, N. Akhmetsadykov and G. Loiseau. 2014. Microflora identification of fresh and fermented camel milk from Kazakhstan. Emirates J. Food Agric. 164: 327-332.

Allison, D. G. and I. W. Sutherland. 1987. Role of exopolysaccharides in adhesion of freshwater bacteria. J. Genet. Microbiol. 133: 1319-1327.

Badel, S., T. Bernardi and P. Michaud. 2011. New perspectives for Lactobacilli exopolysaccharides. Biotechnol. Adv. 29: 54-66.

Badel, S., C. Laroche, C. Gardarin, T. Bernardi and P. Michaud. 2008. New method showing the influence of matrix components in Leuconostoc mesenteroides biofilm formation. Appl. Biochem. Biotechnol. 151: 364-370.

Badis, A., D. Guetarni, B. Moussa-Boudjema, D. E. Henni and M. Kihal. 2004. Identification and technological properties of lactic acid bacteria isolated from raw goat's milk of four Algerian races. Food Microbiol. 21: 579-588. 
Benkerroum, N., A. Boughdadi, N. Bennani and K. Hidane. 2003. Microbiological quality assessment of Moroccan camel's milk and identification of predominating lactic acid bacteria. World $\mathrm{J}$. Microbiol. Biotechnol. 19: 645-648

Bouzar, F., J. Cerning and M. Desmazeaud. 1997. Exopolysaccharide production and texture-promoting abilities of mixed-strain starter cultures in yogurt production, J. Dairy Sci. 80: 2310-2317.

Bradford, M. M. 1976. A rapid and sensitive method for the quantification of microgram quantities of protein utilizing the principle of protein dye-binding. Ann. Biol. 72: 248-254.

Cerning, J. 1990. Exocellular polysaccharides produced by lactic acid bacteria. FEMS Microbiol. Rev. 87: 113-130.

Cerning, J. 1995. Production of exopolysaccharides by lactic acid bacteria and dairy propionibacteria. Le Lait. 75: 463-472.

Cerning, J., M. Bouillanne, M. Desmazeaud and M. Landon. 1986. Isolation and characterization of exocellular polysaccharides by Lactobacillus bulgaricus. Biotechnol. Let. 8: 625-628.

Cerning, J., M. Bouillanne, M. Desmazeaud and M. Landon. 1988. Exocellular polysaccharide production by Streptococcus thermophilus, Biotechnol. Let. 10: 255-260.

Chavant, P., B. Gaillard-Martinie, R. Talon, M. Hébraud and T. Bernardi. 2007. A new device for rapid evaluation of biofilm formation potential by bacteria. J. Microbiol. Methods. 68: 605-612.

Chen, Y., L. Sun, Y. Zeng, L. Wang and L. An. 2006. The productioninfluencing factors of extracellular polysaccharide (EPS) from a strain of lactic acid bacteria and EPS extraction. Front Biol. 3: 236-240.

Criado, M. T., B. Suarez and C. M. Ferreios. 1994. The importance of bacterial adhesion in the dairy industry. Food Technol. 48: $123-126$.

Degeest, B. and L. De Vuyst. 1999. Indication that the nitrogen source influences both amount and size of exopolysaccharides produced by Streptococcus thermophilus LY03 and modeling of the bacterial growth and exopolysaccharide production in a complex medium. Appl. Env. Microbiol. 65: 2863-2870.

Degeest, B., B. Janssens and L. De Vuyst. 2001. Exopolysaccharide (EPS) biosynthesis by Lactobacillus sakei 0-1: Production kinetics, enzyme activities and EPS yields. J. Appl. Microbiol. 91: 470-477.

Degeest, B., F. Mozzi and L. De Vuyst. 2002. Effect of medium composition and temperature and $\mathrm{pH}$ changes on exopolysaccharide yields and stability during Streptococcus thermophilus LY03 fermentations. Int. J. Food Microbiol. 79: 161-174.

De Man, J. C., M. Rogosa and M. E. Sharpe. 1960. A medium for the cultivation of lactobacilli. J. Appl. Bacteriol. 23: 130-135.

Duboc, P. and B. Mollet. 2001. Applications of exopolysaccharides in the dairy industry. Int. Dairy J. 11: 759-768.

Dubois, M., K. A. Gilles, J. K. Hamilton, P. A. Rebers and F. Smith. 1956. Colorimetric method for determination of sugars and related substances. Anal. Chem. 28: 350-356.

Flemming, H. C., T. R. Neu and D. Wozniak. 2007. The EPS matrix: The "House of biofilm cells". J. Bacteriol. 189: 7945-7947.

Free, R. H., H. J. Busscher, G. J. Elving, H. C. van der Mei, R. van Weissenbruch and F. W. J. Albers. 2001. Biofilm formation on voice prostheses: In vitro influence of probiotics. Ann. Otol. Rhinol. Laryngol. 110: 946-951.

Frengova, G. I., E. D. Simova, D. M. Beshkova and Z. I. Simov. 2000. Production and monomer composition of exopolysaccharides by yogurt starter cultures. Can. J. Microbiol. 46: 1123-1127.

Fusconi, R. and M. J. L. Godinho. 2002. Screening for exopolysaccharide-producing bacteria from sub-tropical polluted groundwater. Braz. J. Biol. 62: 363-369.

Garcia-Garibay, M. and V. M. E. Marshall. 1991. Polymer production by Lactobacillus delbrueckii ssp. bulgaricus. J. Appl. Bacteriol. 70: 325-328.

Gancel, F. and G. Novel. 1994. Exopolysaccharide production by Streptococcus salivarius ssp. thermophilus Cultures. 1. Conditions of Production. J. Dairy Sci. 77: 685-688.

Gaudreau, H., C. P. Champagne, J. Conway and R. Degré. 1999. Effect of ultrafiltration of yeast extracts on their ability to promote lactic acid bacteria growth. Can. J. Microbiol. 45: 891-897.

Goh, K. K. T., D. R. Haisman, R. H. Archer and H. Singh. 2005. Evaluation and modification of existing methods for the quantification of exopolysaccharides in milk-based media. Food Res. Int. 38: 605-613.

Gomez, J. 2006. Characterization of exopolysaccharides produced by shalófilos microorganism belonging to the genera Halomonas, Alteromonas, Idiomarina, and Palleronia Salipiger, Thesis (PhD)-University of Granada.

Harrigan, W. F. 1998. A Scheme for the Identification of Gram-Positive Bacteria: Laboratory Methods in Food Microbiology. $3^{\text {rd }}$ ed. Academic Press, London. pp. 337-348.

Jolly, L., S. J. F. Vincent, P. Duboc and J. R. Neeser. 2002. Exploiting exopolysaccharides from lactic acid bacteria. Ant. van Leeuwenhoek. 82: 367-374

Kacem, M. and M. Kaid-Harche. 2008. Probiotic characteristics of Lactobacillus plantarum strains from traditional butter made from camel milk in arid regions (Sahara) of Algeria. Grasas Aceites. 59: 218-224.

Kacem, M. and N. E. Karam. 2006. Physicochemical and microbiological study of "shmen", a traditional butter made from camel milk in the Sahara (Algeria): isolation and identification of lactic acid bacteria and yeasts. Grasas Acietes. 57: 198-204.

Kaur, H., P. Kumar, P. Ray, J. Kaur and A. Chakraborti. 2009. Biofilm formation in clinical isolates of group streptococci from north India. Microb. Pathog. 46: 321-327.

Khedid, K., M. Faid, A. Mokhtari, A. Soulaymani and A. Zinedine. 2009. Characterization of lactic acid bacteria isolated from the one humped camel milk produced in Morocco. Microbiol. Res. 164: 81-91.

Kumar, C. G. and S. K. Anand. 1998. Significance of microbial biofilms in food industry: A review. Int. J. Food Microbiol. 42: 9-27.

Laws, A. P. and V. M. Marshall. 2001. The relevance of exopolysaccharides to the rheological properties in milk fermented with ropy strains of lactic acid bacteria. Int. Dairy J. 11: 709-721.

Laws, A. P., Y. Gu and V. M. Marshall. 2001. Biosynthesis, characterisation, and design of bacterial exopolysaccharides from lactic acid bacteria. Biotechnol. Adv. 19: 597-625.

Leroy, S., I. Lebert, J. P. Chacornac, P. Chavant, T. Bernardi and R. Talon. 2009. Genetic diversity and biofilm formation of Staphylococcus equorum isolated from naturally fermented sausages and their manufacturing environment. Int. J. Food Microbiol. 31: 46-51.

Ludbrook, K. A., C. M. Russell and R. I. Greig. 1997. Exopolysaccharide production from lactic acid bacteria isolated from fermented foods. J. Food Sci. 62: 597-600.

Marshall, V. M. and H. L. Rawson. 1999. Effects of exopolysaccharideproducing strains of thermophilic lactic acid bacteria on the texture of stirred yoghurt. Int. J. Food Sci. Technol. 34: 137-143.

Mayer, C., R. Moritz, C. Kirschner, W. Borchard, R. Maibaum, J. Wingender and H. C. Flemming. 1999. The role of intermolecular 
interactions: Studies on model systems for bacterial biofilms. Int. J. Biol. Macromol. 26: 3-16.

Patel, A. K., P. Michaud, R. R. Singhania, C. R. Soccol and A. Pandey. 2010. Polysaccharides from probiotics: New developments as food additives. Food Tech. Biotechnol. 48: 451-463.

Peterson, S. D. and R. T. Marshall. 1990. Nonstarter lactobacilli in cheddar cheese: A review. J. Dairy Sci. 73: 1395-1410.

Ricciardi, A., E. Parente and F. Clementi. 1997. Exopolysaccharide production in a whey based medium by Streptococcus thermophilus and Lactobacillus delbrueckii subsp. bulgaricus in pure culture and in association. Ann. Microbiol. 47: 213-222.

Ricciardi, A., E. Parente, M. A. Crudele, F. Zanetti, G. Scolari and I. Mannazzu. 2002. Exopolysaccharide production by Streptococcus thermophilus SY: Production and preliminary characterization of the polymer. J. Appl. Microbiol. 92: 297-306.

Ruas-Madiedo, P. and C. G. de los Reyes-Gavilán. 2005. Methods for the screening, isolation, and characterization of exopolysaccharides produced by lactic Acid Bacteria. J. Dairy Sci. 88: 843-856.

Samelis, J., F. Maurogenakis and J. Metaxopoulos. 1994. Characterization of lactic acid bacteria isolated from naturally fermented Greek dry salami. Int. J. Food Microbiol. 23: 179-196.

Sharpe, M. E. 1979. Identification Methods for Microbiologists. Skinner, F. A. and Lovelock, D. W, editors. Academic Press, London. pp. 233-259.

Shene, C., N. Canquil, S. Bravo and M. Rubilar. 2008. Production of the exopolysaccharides by Streptococcus thermophilus: Effect of growth conditions on fermentation kinetics and intrinsic viscosity. Int. J. Food Microbiol. 124: 279-284.

Smitinont, T., C. Tansakul, S. Tanasupawat, S. Keeratipibul, L. Navarini, M. Bosco and P. Cescutti. 1999. Exopolysaccharideproducing lactic acid bacteria strains from traditional Thai fermented foods: Isolation, identification and exopolysaccharide characterization. Int. J. Food Microbiol. 51: 105-111.

Sutherland, I. W. 2001. Exopolysaccharides in biofilms, flocs and related structures. Water Sci. Technol. 43: 77-86.
Tsunda, S., H. Aikawa, H. Hayashi, A. Yuasa and A. Hirata. 2003. Extracellular polymeric substances responsible for bacterial adhesion onto solid surface. FEMS Microbiol. Lett. 223: 287-292.

Van den Berg, D. J. C., A. Smits, B. Pot, A. M. Ledeboer, K. Kersters, J. M. A. Verbakel and C. T. Verrips. 1993. Isolation, screening and identification of lactic acid bacteria from traditional food fermentation processes and culture collections. Food Biotechnol. 7: 189-205.

Vaningelgem, F., M. Zamfir, T. Adriany and L. De Vust. 2004. Fermentation conditions affecting the bacterial growth and exopolysaccharide production by Streptococcus thermophilus ST 111 in milk-based medium. J. Appl. Microbiol. 97: 1257-1273.

Vanos, V. and L. Cox. 1986. Rapid routine method for the detection of lactic acid bacteria among competitive flora. Food Microbiol. 3: 223-234.

Vijayendra, S. V. N., G. Palanivel, S. Mahadevamma and R. N. Tharanathan. 2008. Physicochemical characterization of an exopolysaccharide produced by a non-ropy strain of Leuconostoc sp. CFR 2181 isolated from dahi, an Indian traditional lactic fermented milk product. Carbohydr. Polym. 72: 300-307.

Welman, A. D. and I. S. Maddox. 2003. Exopolysaccharides from lactic acid bacteria: Perspectives and challenges. Trends Biotechnol. 21: 269-274.

Welman, A. D., I. S. Maddox and R. H. Archer. 2003. Screening and selection of exopolysaccharide-producing strains of Lactobacillus delbrueckii subsp. bulgaricus. J. Appl. Microbiol. 95: 1200-1206.

Wong, A. C. L. 1998. Biofilms in food processing environments. J. Dairy Sci. 81: 2765-2770.

Zamfir, M., M. Vancanneyt, L. Makras, F. Vaningelgem, K. Lefebvre, B. Pot, J. Swings and L. De Vuyst. 2006. Biodiversity of lactic acid bacteria in Romanian dairy products. Syst. Appl. Microbiol. 29: 487-495.

Zisu, B. and N. P. Shah. 2003. Effects of pH, temperature, supplementation with whey protein concentrate, and adjunct cultures on the production of exopolysaccharides by Streptococcus thermophilus 1275. J. Dairy Sci. 86: 3405-3415. 